\title{
Age Effect in the Morphological Traits Performance for Sex Determination in Human Skulls and Mandibles
}

\author{
Efecto de la Edad en el Rendimiento de los Rasgos Morfológicos \\ para la Determinación del Sexo en Cráneos y Mandíbulas Humanas. \\ "Iván Suazo Galdames \& ** Daniela Zavando
}

SUAZO, G. I. \& ZAVANDO, D. Age effect in the morphological traits performance for determination in human skulls and mandibles. Int. J. Morphol., 30(1):296-301, 2012.

SUMMARY: In this study we tested the hypothesis that diagnostic performance of the morphological indicators for sexual dimorphism are reduced as they are applied in skull and mandibles of older subjects. We used 275 adult human skulls, 250 of these with mandible, all subjects with sex and age registry. Sixteen classic morphological indicators of sexual dimorphism were evaluated, this information was compared with the registry and results noted in terms of precision. The best general performance of morphological indicators of sexual dimorphism were recorded in the 31 - 40 and 61 - 70 years, age range groups. Lowest precision ws recorded in the group corresponding to subjects between 21 - 30 years. Our results do not support the proposed hypothesis and suggest a progressive and cumulative effect of factors that determine dimorphism expression.

KEY WORDS: Sexual dimorphism; Sex determination; Aging, Age; Skull.

\section{INTRODUCTION}

Performance in terms of precision and error of quantitative methods for sex determination have been extensively documented for most skeletal elements, the sensitivity of these diagnostic methods of sex, change according to the bone, while those that surpass the $90 \%$ are considered useful. The skull occupies the second place in the expression of sexual dimorphism, immediately following the pelvis (Bidmos \& Asala, 2003, Introna et al., 1993, Introna et al., 1998; Suazo et al., 2008a; Cantín et al., 2009; Suazo et al., 2009a; Zavando et al., 2009).

Sex determination is more exact in adults than in subadults as a result of the effect of sexual hormones, estrogen and progesterone on the development of morphological differences that have their maximum expression at the onset of puberty (Suazo et al., 2009b). Hormones control development and growth of bones; differences between the sexes occur as a result of different bone development velocities and forces. Women complete their development earlier than men who modify their appearance drastically during puberty. Consequently bio-morphological differences between the sexes manifest more evidently in adult skeletons (Krenzer, 2006; Suazo et al., 2008b).

\footnotetext{
* Facultad de Medicina. Universidad Diego Portales, Santiago, Chile. ** Universidad Autónoma de Chile, Talca, Chile.
}

For Baughan \& Demirjian (1978), sexual dimorphism in the skull appears during puberty when $95 \%$ of cranium growth has already occurred, subsequently differences increase lineally until the balance range is attained in each sex after 25 years of age.

Socio-ecological differences are also observed (for instance nutrition, diet, climate, pathologies etc.) that model bone development and aspect (Park \& NowosielskiSlepowron, 1983; Suazo et al., 2008c).

Additionally bone structure is the function's logical consequence; bones are shaped according to their specific biomechanical needs. Muscle structure determines bone elevation, and with a stronger muscular insertion cortical thickness increases proportionally (Krenzer, 2006; Suazo et al., 2008d).

Along with the development of skeletal manifestation of dimorphism in the post pubertal stage, differences can also be found in the integuments covering the head bone. (Blanchette et al., 1996; Suazo et al., 2007) Bulygina et al. (2006) note that sexual dimorphism in subjects presents at 
an early age. They found little correlation between morphology of newborn and adult subjects. However when analyzing these subjects in their third year of life they always described a high correlation with the adult shape, thus concluding that the inter individual differences in facial and skull shape are established during the first years of life.

The most commonly used morphological indicators of sexual dimorphism were evaluated by Rogers (2005) describing them precisely which was corroborated Suazo et al. (2009c), who reported that the best indicators were those that formed in relation to muscle forces that shape them. Therefore, age of the subjects at the time of sampling may be a relevant factor when determining performance of the morphological indicators for sexual dimorphism. Krogman \& Iscan 1986 proposed to analyze only skulls of subjects between 25 and 55 years of age, since hormonal influence determining sexual dimorphism manifests in that age range, these authors indicated that sex determination in subjects under 25 years of age and older than 55 years of age implied greater levels of error. (Krogman and Iscan).

Considering this information, the purpose of this study is to evaluate the effect of age in the performance of skull morphological indicators of sexual dimorphism most commonly used.

\section{MATERIAL AND METHOD}

We designed a cross sectional study for evaluation of the diagnostic test. 275 human skulls of adult subjects were used from the collection of Universidade Federal de Sao Paulo,

Table I. Distribution of skulls analyzed in the various age groups.

\begin{tabular}{llll}
\hline Range of age & Men & Women & Total \\
\hline $21-30$ & 25 & 33 & 58 \\
$31-40$ & 53 & 39 & 92 \\
$41-50$ & 41 & 21 & 62 \\
$51-60$ & 31 & 10 & 41 \\
$61-70$ & 16 & 6 & 22 \\
Total & 166 & 109 & 275 \\
\hline
\end{tabular}

250 all with mandible. Only skulls with complete sex and age registry were included and those presenting extensive destruction or apparent dysmorphism were not considered. Skulls and mandibles were classified in groups according to age. Table I notes distribution of skulls in the various age groups.

Dimorphism Analysis. Sixteen indicators of classical morphological sexual dimorphism, as described by Krogman and Krogman \& Iscan were analyzed: Size and architecture of the skull, forehead shape, frontal eminences, superciliary arches, orbital shape, piriform aperture, nasal bone, zygomatic bone, zygomatic arch, parietal eminences, mastoid process, occipital bone, occipital condyles, shape of the palate, general appearance of the mandible, and chin shape.

If one of the indicators was partially or completely destroyed, it was not considered and the remainder of indicators was evaluated.

All skulls were independently evaluated according to procedure described by Suazo et al., 2009c, sex registry was concealed from the researchers. Results obtained were based on contrast between diagnosis and registry, which were expressed in terms of general precision and sensitivity for the diagnosis of men and women.

\section{RESULTS}

Best general performance of morphological indicators of sexual dimorphism were found in age ranges from 31 to 40 and 61 to 70 years, best precision was found in the group corresponding to subjects between 21-30 years. Details of general accuracy values are in Table II and are illustrated in Figure 1.

\section{General Performance}

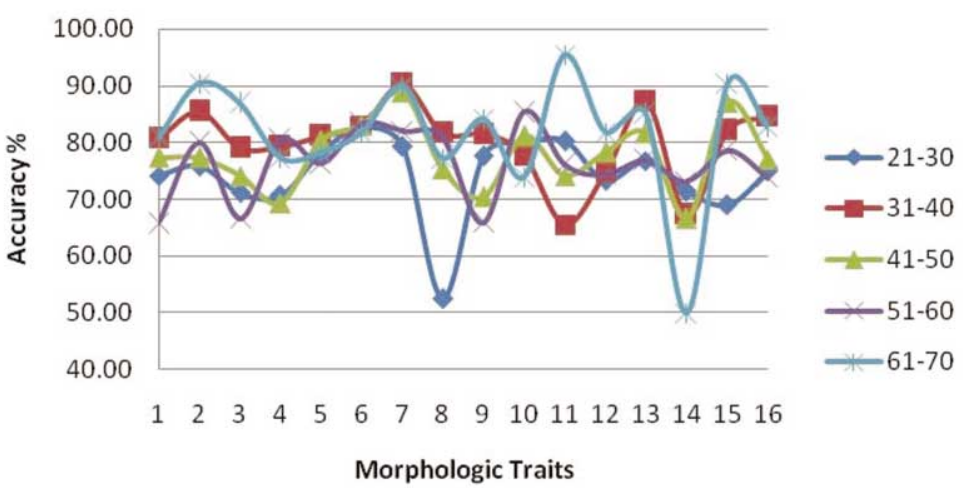

Fig. 1. Diagram of the distribution of precision percentage of the 16 indicators evaluated. 1. Chin shape; 2 . General appearance of the mandible; 3. Piriform aperture; 4. Orbital shape; 5 . Nasal bone; 6 . Zygomatic bone; 7. Mastoid process; 8. Palate shape; 9. Frontal eminences; 10. Forehead shape; 11. Size and architecture of the skull; 12. Zygomatic arch; 13. Occipital condyles; 14. Parietal eminences; 15 . Occipital bone; 16. Superciliary arches. 
Table II. General precision of the 16 morphological indicators of sexual dimorphism grouped by age range.

\begin{tabular}{lccccccc}
\hline \multicolumn{1}{c}{ Morphologic Traits } & \multicolumn{7}{c}{ Age } \\
& $\mathbf{2 1 - 3 0}$ & $\mathbf{3 1 - 4 0}$ & $\mathbf{4 1 - 5 0}$ & $\mathbf{5 1 - 6 0}$ & $\mathbf{6 1 - 7 0}$ & \multicolumn{1}{c}{ Mean } & \multicolumn{1}{c}{ SD } \\
\hline 1. C hin shape & 74.14 & 80.72 & 77.36 & 65.71 & 80.95 & 75.78 & 6.28 \\
2. G eneral appearance of the mandible & 75.86 & 85.54 & 77.36 & 80.00 & 90.48 & 81.85 & 6.07 \\
3. P iriform aperture & 71.19 & 79.12 & 74.14 & 66.67 & 86.96 & 75.61 & 7.79 \\
4. O rbital shape & 70.69 & 79.35 & 69.35 & 80.49 & 77.27 & 75.43 & 5.09 \\
5. N asal bone & 78.33 & 81.18 & 80.33 & 76.32 & 78.26 & 78.88 & 1.91 \\
6. Z ygomatic bone & 82.76 & 82.98 & 83.05 & 83.33 & 81.82 & 82.79 & 0.58 \\
7. M astoid process & 79.31 & 90.32 & 88.89 & 82.05 & 90.00 & 86.11 & 5.08 \\
8. P alate shape & 52.54 & 81.72 & 75.41 & 80.95 & 77.27 & 73.58 & 12.04 \\
9. F rontal eminences & 77.59 & 81.52 & 70.49 & 65.85 & 84.21 & 75.93 & 7.64 \\
10. f orehead shape & 80.00 & 77.78 & 81.25 & 85.37 & 73.91 & 79.66 & 4.24 \\
11. S ize and architecture of the skull & 80.33 & 65.52 & 74.19 & 76.19 & 95.45 & 78.34 & 10.99 \\
12. Z ygomatic arch & 73.33 & 74.71 & 78.33 & 74.42 & 81.82 & 76.52 & 3.51 \\
13. O ccipital condyles & 76.79 & 87.21 & 81.67 & 76.92 & 85.00 & 81.52 & 4.69 \\
14. P arietal eminences & 71.43 & 67.37 & 66.67 & 73.17 & 50.00 & 65.73 & 9.20 \\
15. O ccipital bone & 68.97 & 82.22 & 87.10 & 78.57 & 90.48 & 81.47 & 8.34 \\
16. S uperciliary arches & 75.00 & 84.62 & 77.05 & 73.81 & 82.61 & 78.62 & 4.76 \\
Mean & 74.27 & 80.12 & 77.66 & 76.24 & 81.66 & & \\
SD & 7.00 & 6.50 & 6.07 & 6.09 & 10.25 & & \\
\hline
\end{tabular}

Sensitivity in Men Skulls

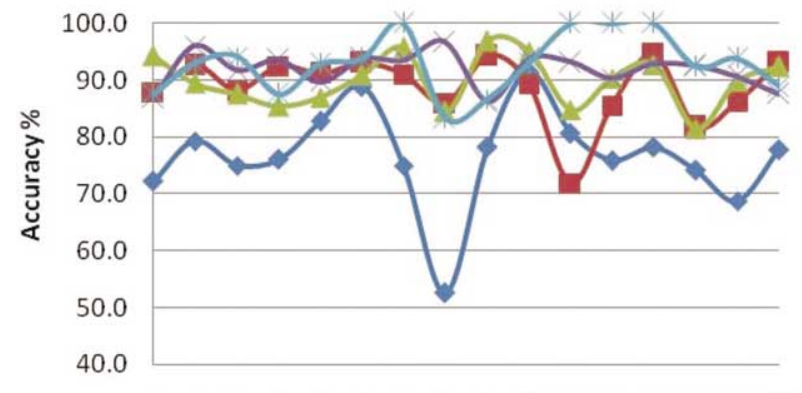

$\begin{array}{llllllllllllllll}1 & 2 & 3 & 4 & 5 & 6 & 7 & 8 & 9 & 10 & 11 & 12 & 13 & 14 & 15 & 16\end{array}$

Morphologic traits

\section{Sensitivity in Women Skulls}

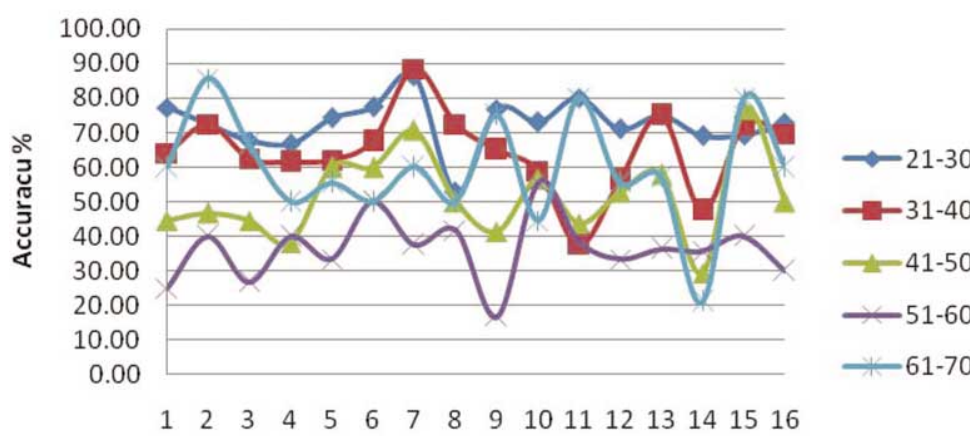

Fig. 2. Diagram of the distribution of precision percentage of the 16 indicators evaluated in skulls of men. 1. Chin shape; 2. General appearance of the mandible; 3. Piriform aperture; 4. Orbital shape; 5. Nasal bone; 6. Zygomatic bone; 7. Mastoid process; 8. Palate shape; 9. Frontal eminences; 10. Forehead shape; 11. Size and architecture of the skull; 12. Zygomatic arch; 13. Occipital condyles; 14. Parietal eminences; 15 . Occipital bone; 16 . Superciliary arches

Fig. 3. Diagram of the distribution of precision percentage of the 16 indicators evaluated in skulls of women. 1. Chin shape; 2 . General appearance of the mandible; 3. Piriform aperture; 4. Orbital shape; 5. Nasal bone; 6. Zygomatic bone; 7. Mastoid process; 8. Palate shape; 9. Frontal eminences; 10. Forehead shape; 11. Size and architecture of the skull; 12. Zygomatic arch; 13. Occipital condyles; 14. Parietal eminences; 15 . Occipital bone; 16 . Superciliary arches

Morphologic Traits 
In the skulls of men greater performance values were observed, and in this group a lineal and progressive increase of sensitivity values was observed from the younger group to that of greater age. Detail of performance values for Table III. Sensitivity for men of the 16 morphological indicators of sexual dimorphism grouped by age range.

\begin{tabular}{|c|c|c|c|c|c|c|c|}
\hline \multirow[t]{2}{*}{ Morphologic Traits } & \multicolumn{5}{|c|}{ Age } & \multirow[b]{2}{*}{ Mean } & \multirow[b]{2}{*}{ SD } \\
\hline & 21-30 & $31-40$ & $41-50$ & $51-60$ & $61-70$ & & \\
\hline 1. C hin shape & 72.2 & 87.9 & 94.3 & 87.0 & 87.5 & 85.8 & 8.1 \\
\hline 2. G eneral appearance of the mandible & 79.3 & 92.6 & 89.5 & 96.0 & 92.9 & 90.0 & 6.4 \\
\hline 3. $P$ iriform aperture & 75.0 & 88.1 & 87.5 & 91.7 & 94.1 & 87.3 & 7.4 \\
\hline 4. O rbital shape & 76.0 & 92.5 & 85.4 & 93.5 & 87.5 & 87.0 & 7.0 \\
\hline 5. $\mathbf{N}$ asal bone & 82.8 & 91.1 & 87.0 & 89.7 & 92.9 & 88.7 & 3.9 \\
\hline 6. Z y gomatic bone & 88.9 & 93.0 & 90.9 & 93.8 & 93.8 & 92.1 & 2.1 \\
\hline 7. M astoid process & 75.0 & 91.0 & 95.7 & 93.5 & 100.0 & 91.0 & 9.6 \\
\hline 8. P alate shape & 52.5 & 85.9 & 84.4 & 96.7 & 83.3 & 80.6 & 16.6 \\
\hline 9. F rontal eminences & 78.1 & 94.2 & 96.9 & 86.2 & 86.7 & 88.4 & 7.4 \\
\hline 10. f orehead shape & 91.3 & 89.3 & 95.1 & 93.8 & 92.9 & 92.5 & 2.3 \\
\hline 11. $S$ ize and architecture of the skull & 80.6 & 71.8 & 84.8 & 93.1 & 100.0 & 86.1 & 10.9 \\
\hline 12. $\mathrm{Z}$ ygomatic arch & 75.9 & 85.5 & 90.2 & 90.3 & 100.0 & 88.4 & 8.8 \\
\hline 13. O ccipital condyles & 78.1 & 94.4 & 92.7 & 92.9 & 100.0 & 91.6 & 8.1 \\
\hline 14. $P$ arietal eminences & 74.1 & 81.8 & 81.4 & 92.6 & 92.3 & 84.4 & 7.9 \\
\hline 15. O ccipital bone & 68.8 & 86.2 & 89.8 & 90.6 & 93.8 & 85.8 & 9.9 \\
\hline 16. $S$ uperciliary arches & 77.8 & 93.1 & 92.3 & 87.5 & 88.9 & 87.9 & 6.1 \\
\hline Mean & 76.6 & 88.7 & 89.9 & 91.8 & 92.9 & & \\
\hline SD & 8.6 & 5.8 & 4.5 & 3.1 & 5.2 & & \\
\hline
\end{tabular}

Table IV. Sensitivity for women of the 16 morphological indicators of sexual dimorphism grouped by age range.

\begin{tabular}{|c|c|c|c|c|c|c|c|}
\hline \multirow[t]{2}{*}{ Morphologic Traits } & \multicolumn{5}{|c|}{ Age } & \multirow[b]{2}{*}{ Mean } & \multirow[b]{2}{*}{ SD } \\
\hline & 21-30 & $31-40$ & $41-50$ & $51-60$ & $61-70$ & & \\
\hline 1. C hin shape & 77.27 & 64.00 & 44.44 & 25.00 & 60.00 & 54.14 & 20.06 \\
\hline 2. G eneral appearance of the mandible & 72.41 & 72.41 & 46.67 & 40.00 & 85.71 & 63.44 & 19.28 \\
\hline 3. $\mathbf{P}$ iriform aperture & 67.74 & 62.50 & 44.44 & 26.67 & 66.67 & 53.60 & 17.74 \\
\hline 4. O rbital shape & 66.67 & 61.54 & 38.10 & 40.00 & 50.00 & 51.26 & 12.69 \\
\hline 5. $\mathrm{N}$ asal bone & 74.19 & 62.07 & 60.00 & 33.33 & 55.56 & 57.03 & 14.93 \\
\hline 6. Z ygomatic bone & 77.42 & 67.57 & 60.00 & 50.00 & 50.00 & 61.00 & 11.78 \\
\hline 7. M astoid process & 86.36 & 88.46 & 70.59 & 37.50 & 60.00 & 68.58 & 20.94 \\
\hline 8. P alate shape & 52.63 & 72.41 & 50.00 & 41.67 & 50.00 & 53.34 & 11.43 \\
\hline 9. F rontal eminences & 76.92 & 65.00 & 41.38 & 16.67 & 75.00 & 54.99 & 25.66 \\
\hline 10. f orehead shape & 72.97 & 58.82 & 56.52 & 55.56 & 44.44 & 57.66 & 10.20 \\
\hline 11. $S$ ize and architecture of the skull & 80.00 & 37.50 & 43.75 & 38.46 & 80.00 & 55.94 & 22.09 \\
\hline 12. Z y gomatic arch & 70.97 & 56.25 & 52.63 & 33.33 & 55.56 & 53.75 & 13.45 \\
\hline 13. O ccipital condyles & 75.00 & 75.00 & 57.89 & 36.36 & 57.14 & 60.28 & 15.97 \\
\hline 14. $P$ arietal eminences & 68.97 & 47.50 & 29.41 & 35.71 & 21.05 & 40.53 & 18.59 \\
\hline 15. O ccipital bone & 69.23 & 72.00 & 76.92 & 40.00 & 80.00 & 67.63 & 16.00 \\
\hline 16. S uperciliary arches & 72.73 & 69.70 & 50.00 & 30.00 & 60.00 & 56.48 & 17.27 \\
\hline Mean & 72.59 & 64.55 & 51.42 & 36.27 & 59.45 & & \\
\hline SD & 7.30 & 11.66 & 12.05 & 9.30 & 15.98 & & \\
\hline
\end{tabular}


morphological indicators of sexual dimorphism expressed in terms of sensitivity to diagnose men is noted in Table II and is illustrated in Figure 2.

In the skulls of women performance of indicators of sexual dimorphism analyzed was low at all ages. Contrary to what occurred in the skulls of men, sensitivity diminished from the younger group up to the group between 51 to 60 years, with a significant increase in the greater age group, although without attaining good performance. Detail of performance values of morphological indicators of sexual dimorphism analyzed in terms of sensitivity for women are observed in Table IV and illustrated in Figure 3.

\section{DISCUSSION}

In this study we tested the hypothesis that age influences in the performance of morphological indicators of sexual dimorphism in skulls. Particularly those that are expressions of the forces applied on certain bone surfaces, whereas the intensity of the forces and thickness of cortical bone decreased in older individuals (Lauretani et al., 2006; Russo et al., 2006), which would increase the classification error range. Our results do not support this hypothesis, we observed better levels of diagnostic precision in the groups of skulls of older individuals (61-70 years). This information differs with that indicated by Krogman \& Iscan, who did not recommend evaluation of sexual dimorphism in individuals older than 55 years. Our results suggest a cumulative effect in the expression of dimorphism, consequently with the passage of time these characteristics become permanent. Nevertheless, an evaluation of the life history of the subject would be necessary as the effects of exercise and nutrition have been noted. (Suazo et al., 2008c).

Sexual dimorphism is the expression of functional modeling of the skull and face and starting from a male or female pattern that begins acquiring characteristic phenotypical features. There is an over expression of bone elevations in this process; ridges, tubercles processes etc., that characterize men and differentiate them from women. This development is related with differences in size and muscle mass. (Wells, 2007). It is probable that emphasis which exists in the observation of major development areas may confuse the diagnosis, and some interpreted as male characteristics, namely for their size, underestimating women, thereby reducing diagnostic performance of the tests. Consequently, additional diagnostics along with others as observation of sexual chromatin or advanced morphometric methods is recommended. (Kimmerle et al., 2008; Suazo et al., 2010; Toro et al., 2010; Suazo et al., 2011).

SUAZO, G. I. \& ZAVANDO, D. Efecto de la edad en el rendimiento de los rasgos morfológicos. Int. J. Morphol., 30(1):296-301, 2012.

RESUMEN: En este estudio testeamos la hipótesis que el rendimiento diagnóstico de los indicadores morfológicos de dimorfismo sexual disminuía al aplicarlos en cráneos y mandíbulas de individuos de mayor edad. Utilizamos 275 cráneos humanos adultos, 250 de los cuales tenían mandíbula, todos con registro de sexo y edad. Se evaluaron 16 indicadores morfológicos clásicos de dimorfismo sexual, estos datos se contrastaron con el registro y los resultados se expresaron en términos de exactitud. El mejor rendimiento general de los indicadores morfológicos de dimorfismo sexual se encontraron en los rangos etarios de 31-40 y de 61-70 años, la menor exactitud se encontró en el grupo correspondiente a individuos de entre 21-30 años. Nuestros resultados no sustentan la hipótesis propuesta y sugieren un efecto progresivo y acumulativo de los factores que determinan la expresión de dimorfismo.

PALABRAS CLAVE: Dimorfismo sexual; Determinación de sexo; Envejecimiento; Edad; Cráneo.

\section{REFERENCES}

Baughan, B. \& Demirjian, A. Sexual dimorphism in the growth of the cranium. Am. J. Phys. Anthropol., 49:383-90, 1978.

Bidmos, M. A. \& Asala, S. A. Discriminant function sexing of the calcaneus of the South African whites. J. Forensic Sci., 48:1213-8, 2003.

Blanchette, M. E.; Nanda, R. S.; Currier, G. F.; Ghosh, J. \& Nanda, S. K . A longitudinal cephalometric study of the soft tissue profile of short- and long-face syndromes from 7 to 17 years. Am. J. Orthod. Dentofacial Orthop., 109:116-31, 1996.
Bulygina, E.; Mitteroecker, P. \& Aiello, L. Ontogeny of facial dimorphism and patterns of individual development within one human population. Am. J. Phys. Anthropol., 131:432-43, 2006.

Cantín, L. M.; Suazo, G. I. C; Zavando, M. D. A \& Smith, R. L. Sexual dimorphism determination by piriform aperture morphometric analysis in Brazilian human skulls. Int. J. Morphol., 27(2):327-31, 2009.

Introna, F. Jr.; Cantatore, F.; Dragone, M. \& Colonna, M. Sexual dimorphism of deciduous teeth in medico-legal identification. Boll. Soc. Ital. Biol. Sper., 69:223-30, 1993. 
Introna, F. Jr.; Di Vella, G. \& Campobasso, C. P. Sex determination by discriminant analysis of patella measurements. Forensic Sci. Int., 95:39-45, 1998.

Kimmerle, E. H.; Ross, A. \& Slice, D. Sexual dimorphism in America: geometric morphometric analysis of the craniofacial region. J. Forensic Sci., 53:54-7, 2008.

Krenzer, U. Compendio de Métodos Antropológico Forenses, Guatemala, 2006.

Krogman, W. E. \& Iscan, M. Y. The Human Skeleton in Forensic Medicine. Springfield, Charles C. Thomas, 1986.

Lauretani F, Bandinelli S, Russo CR, Maggio M, Di Iorio A, Cherubini A, Maggio D, Ceda GP, Valenti G, Guralnik JM, Ferrucci L. Correlates of bone quality in older persons. Bone, 39:915-21, 2006.

Park, A. W. \& Nowosielski-Slepowron, B. J. Postnatal skull growth of the rat relative to environmental variance. Acta Morphol. Neerl. Scand., 21:141-63, 1983.

Rogers, T. L. Determining the sex of human remains through cranial morphology. J. Forensic Sci., 50:493-500, 2005.

Russo CR, Lauretani F, Seeman E, Bartali B, Bandinelli S, Di Iorio A, Guralnik J, Ferrucci L. Structural adaptations to bone loss in aging men and women. Bone, 38:112-8, 2006.

Suazo, G. I.; Zavando, M. D.; Russo, P. \& Smith, R. L. Evaluation of the Baudoin condylar index diagnostic test for sex determination. Int. J. Morphol., 28(1):171-4, 2010.

Suazo, G. I. C.; Russo, P.; Zavando, M. D. A. \& Smith, R. L. Sexual dimorphism in the foramen magnum dimensions. Int. J. Morphol., 27(1):21-3, 2009a.

Suazo, G. I. C.; Salgado, A. G. E.; Cantín, L. M. G. Evaluación ultrasonográfica del tejido blando facial en adultos chilenos. Int. J. Morphol., 25(3):643-8, 2007.

Suazo, G. I. C.; Zavando, M. D. A \& Smith, R. L. Evaluating accuracy and precision in morphologic traits for sexual dimorphism in malnutrition human skull: a comparative study. Int. J. Morphol., 26(4):876-83, 2008 b.

Suazo, G. I. C.; Zavando, M. D. A. \& Smith, R. L. Blind test of mandibular morphology with sex indicator in subadult mandibles. Int. J. Morphol., 26(4):845-8, 2008a.

Suazo, G. I. C.; Zavando, M. D. A. \& Smith, R. L. Sex determination in mandibles in the first year of life by a quantitative approach. Int. J. Morphol., 27(1): 113-6, 2009b.

Suazo, G. I. C.; Zavando, M. D. A. \& Smith, R. L. Sex determination using mastoid process measurements in Brazilian skulls. Int. J. Morphol., 26(4):941-4, 2008c.
Suazo, G. I. C; San Pedro, V. J.; Schilling, Q. N. A.; Celis C. C. E.; Hidalgo, R. J. A. \& Cantín, L. M. Ortopantomographic blind test mandibular ramus flexure as a morphological indicator of sex in Chilean young adults. Int. J. Morphol., 26(1):89-92, 2008d.

Suazo, G. I.; Flores, A.; Roa, I.; Cantín, M. \& Zavando, D. Sex determination by observation of Barr body in teeth subjected to high temperatures. Int. J. Morphol.,29 (1): 199-203, 2011.

Suazo, G. I.; Roa, H. I. \& Cantín, L. M. Sex chromatin in dental pulp. Performance of diagnosis test and gold standard generation. Int. J. Morphol., 28(4):1093-6, 2010.

Suazo, G. I.; Zavando, M. D.; Smith, R. L. Performance Evaluation as a Diagnostic Test for Traditional Methods for Forensic Identification of Sex. Int. J. Morphol., 27(2):381-386, 2009c.

Toro, I. V.; Manriquez, G. \& Suazo, G. I. Geometric Morphometry and the Biologic Shapes Study: From the Descriptive Morphology to the Quantitative Morphology. Int. J. Morphol., 28(4): 977-90, 2010.

Wells JC. 2007. Sexual dimorphism of body composition. Best Pract. Res. Clin .Endocrinol. Metab., 21:415-30.

Zavando, M. D. A.; Suazo, G. I. C. \& Smith, R. L. Sexual dimorphism determination in the lineal dimensions of skulls. Int. J. Morphol., 27(1):133-7, 2009.

\section{Correspondence to: \\ Prof. Dr. Iván Suazo Galdames \\ Universidad Diego Portales \\ Santiago \\ CHILE}

Email: ivan.suazo@udp.cl

Received: 06-09-2011

Accepted: 22-11-2011 